\title{
Succession of protease activity in seawater and bacterial isolates during starvation in a mesocosm experiment
}

\author{
Chui Wei Bong ${ }^{1,2,3, *}$, Yumiko Obayashi ${ }^{1,4}$, Satoru Suzuki ${ }^{1}$ \\ ${ }^{1}$ Center for Marine Environmental Studies (CMES), Ehime University, Matsuyama 790-8577, Japan \\ ${ }^{2}$ Institute of Biological Sciences, Faculty of Science, University of Malaya, 50603 Kuala Lumpur, Malaysia \\ ${ }^{3}$ Institute of Ocean and Earth Sciences (IOES), University of Malaya, 50603 Kuala Lumpur, Malaysia \\ ${ }^{4}$ Faculty of Engineering, Yokohama National University, Yokohama 240-8501, Japan
}

\begin{abstract}
Protein biodegradation in the marine environment is caused by proteases derived from various organisms, including bacteria, which are considered to be a major source of these enzymes. We investigated the succession of bacterial proteases in seawater to determine the variation in protease activity over time. The potential activities of proteolytic enzymes in stored seawater and isolated bacteria were studied using 19 different synthetic oligopeptide substrates for aminopeptidase, trypsin, chymotrypsin and elastase. In time-course experiments carried out over $112 \mathrm{~d}$, aminopeptidase activity increased, whereas trypsin activity decreased over time. Aminopeptidase activity was mainly found in unfiltered seawater containing bacterial cells, whereas trypsin activity was mainly found in $0.2 \mu \mathrm{m}$ seawater filtrates. Individual bacterial isolates showed different proteolytic properties but all exhibited aminopeptidase activity. Members of the Gammaproteobacteria and Bacteroidetes showed high trypsin and chymotrypsin activities. Based on these results, we conclude that protein degradation in seawater occurs via the combined action of various bacterial proteases.
\end{abstract}

KEY WORDS: Bacterial protease - Aminopeptidase - Trypsin - Cell-associated enzymes · Dissolved fraction · Seawater

\section{INTRODUCTION}

Heterotrophic bacteria are major degraders of organic matter in seawater and numerous studies have shown that they play an important role in carbon flux in the marine ecosystem (Cottrell \& Kirchman 2000, Azam \& Worden 2004, Nagata 2008). Most of the bioavailable dissolved organic matter in seawater is present as high molecular weight molecules (Benner 2002). These need to be hydrolyzed by extracellular enzymes prior to bacterial uptake, as transport of organic molecules across the bacterial cell membrane is limited to monomers or small polymers (Nikaido \& Vaara 1985, Hoppe et al. 2002).
Proteins are important macromolecules for the structure and function of all living organisms. In the seawater environment, proteins comprise 5 to $20 \%$ of dissolved organic nitrogen and 3 to $4 \%$ of dissolved organic carbon (Sharp 1983, Thurman 1985) and are correlated with bacterial growth (Rosso \& Azam 1987, Benner et al. 1992, Keil \& Kirchman 1993). A wide variety of proteolytic enzymes are consistently found in the marine environment and play a role in the degradation and modification of marine proteins prior to cellular uptake (Hoppe et al. 2002).

Bacterial proteases are either released into the marine environment or present as ecto-enzymes (cell-associated forms). Previous studies have reported dissolved enzyme activity in seawater, as well as 
that associated with bacteria-size particles (Hoppe 1983, Karner \& Rassoulzadegan 1995, Pantoja et al. 1997, Hoppe et al. 2002, Obayashi \& Suzuki 2008). Enzyme activity intensifies in suspended and sinking organic aggregates (Smith et al. 1992, Taylor et al. 2009). Furthermore, culture supernatants of marine bacteria contain many types of proteases (Odagami et al. 1994), indicating that bacteria release proteases into the environment. Sequential degradation of proteins by the combined action of various proteases is believed to occur in aquatic ecosystems. However, the specific bacterial groups responsible for protein degradation in seawater are still unknown. Therefore, the origin of proteolytic enzymes in seawater and the contribution of various groups of bacteria to the pool of proteolytic enzymes are of interest.

In this study, we examined the changes in proteolytic activity on several protein substrate analogues due to starvation in a long-term microcosm. Enzymes from isolated bacteria were also characterized to evaluate their potential role in protein degradation in the aquatic ecosystem.

\section{MATERIALS AND METHODS}

\section{Sampling}

Surface seawater samples were collected from the Matsuyama coast, Ehime Prefecture, Japan (335 $54^{\prime}$ $23.9^{\prime \prime} \mathrm{N}, 132^{\circ} 34.2^{\prime} \mathrm{E}$ ), in January 2009. The surface seawater temperature and salinity were $13^{\circ} \mathrm{C}$ and 35 , respectively. The monthly profile of proteolytic activity at the sampling site has been reported by Obayashi \& Suzuki (2005). Seawater was pre-filtered through a $150 \mu \mathrm{m}$ plankton net and kept cold until it was processed within 2 to $3 \mathrm{~h}$. The seawater sample used for the time-course experiment was stored in 101 tanks maintained at 20 to $25^{\circ} \mathrm{C}$ in the dark. Subsamples were withdrawn from the stored seawater tank at Days 0, 28, 56, 84 and 112. The natural concentration of the protein in this area was at a nondetectable level according to Coomassie brilliant blue-R250 staining on polyacrylamide gel (Obayashi et al. 2010).

\section{Enzyme assay}

Enzymatic activity was analyzed using synthetic peptide analogue 4-methyl-coumaryl-7-amide (MCA) substrates according to the procedure described by Obayashi \& Suzuki (2005). Nineteen MCA substrates for aminopeptidase, trypsin, chymotrypsin and elastase (Table 1) were used to examine the enzyme substrate specificity in seawater samples. Each substrate was added to triplicate $1 \mathrm{ml}$ seawater samples at a final concentration of $100 \mu \mathrm{M}$, which was reported as a saturating concentration by Obayashi \& Suzuki (2005). Mixtures of sample and substrates were incubated in disposable cuvettes at $25^{\circ} \mathrm{C}$ for $1 \mathrm{~h}$. The fluorescence of the released 7-amino-4-methylcoumarin (AMC) moiety was measured before and after incubation using a spectrofluorometer (Hitachi F2500) at excitation/emission wavelengths of 380/ $460 \mathrm{~nm}$. The fluorescence signal was converted to AMC concentration using a calibration curve. The potential hydrolysis rates of substrates were determined after subtracting the blank florescence intensity of seawater (without added substrate) and nonenzymatic production of AMC. This was determined by analysing autoclaved filtered seawater with substrates, and is reported here as nanomoles of substrate per liter per hour of sampled seawater (nmol $\mathrm{l}^{-1}$ 
$\mathrm{h}^{-1}$ ). Total enzyme activity was measured in unfiltered seawater samples and dissolved enzyme activity was measured in the $0.2 \mu \mathrm{m}$ filtrate (Nuclepore, Whatman). Cell-associated enzyme activity was expressed as the difference between the total and dissolved enzyme activities.

\section{Bacterial count}

The total bacterial cell count was performed using an epifluorescence microscope (Olympus BX51, Japan) following filtration of a $2 \mathrm{ml}$ sample onto a $0.2 \mu \mathrm{m}$ black polycarbonate filter (Nuclepore, Whatman). The filter was stained with 4',6-diamidino-2phenylindole (DAPI) (0.1 $\mathrm{g} \mathrm{m} \mathrm{ml}^{-1}$ final concentration) for $7 \mathrm{~min}$ and $>300$ cells were counted for each sample.

\section{Bacterial isolation, identification and enzyme assay}

Bacteria were isolated from the stored seawater microcosm by spreading a $0.1 \mathrm{ml}$ aliquot of seawater onto a marine agar plate (Marine broth 2216 [Difco] plus $1.5 \%$ agar) in triplicate and incubation at $25^{\circ} \mathrm{C}$ for $2 \mathrm{~d}$. Eighteen morphologically different bacterial colonies were obtained from Days 0, 56, 84 and 112 (total 72 strains). All colonies were re-streaked twice to ensure bacterial purity. Protease assays using cultured bacteria were performed by inoculating one colony of each bacterial isolate (at $\times 10^{5}$ cells $\mathrm{ml}^{-1}$ ) into autoclaved filtered seawater. No other source of protein was added into the seawater. This was incubated at $25^{\circ} \mathrm{C}$ for $2 \mathrm{~d}$ with mild shaking at $100 \mathrm{rpm}$. After incubation, the bacterial suspension was separated into total (unfiltered) and dissolved $(<0.2 \mu \mathrm{m})$ fractions and tested using the protease assay procedures described above. The classification of isolates was determined using 16S rDNA sequencing. Universal forward (341F: 5'-CCT ACG GGA GGC AGC AG-3') and reverse (907R: 5'-CCG TCA ATT CMT TTG AGT TT-3') primers were used to produce an amplicon of approximately $566 \mathrm{bp}$. PCR was carried out according to the method of Muyzer et al. (1993). The 16S rDNA sequences of each isolate were aligned with related reference species from the database of the National Centre for Biotechnology Information (NCBI, http://blast.ncbi.nlm.nih.gov/Blast .cgi) using the Basic Local Alignment Search Tool (BLAST). Sequences were aligned using ClustalW in the software package BioEdit (v.5.0.9). Phylogenetic analysis was conducted using the neighbor-joining method with 1000 bootstrap replications (Thompson et al. 1997). Phylogenetic trees were visualized and edited with TreeView software using Nanoarchaeum equitans (AJ318041) as a defined out-group.

Due to the extensive work-load resulting from the application of enzymatic and molecular techniques, we were not able to process more than one mesocosm. We only wanted to give an example and to stimulate further investigations on the topic of our study.

\section{Statistical analysis}

One-way ANOVA combined with post hoc Tukey$B$ tests were used to compare enzymatic activities at time intervals and analyze the effect of storage duration on enzymatic activity. The paired-sample $t$-test was used to compare the potential enzymatic activity level of the unfiltered and $<0.2 \mu \mathrm{m}$ fractions. Principal component analysis (PCA) was applied to evaluate the similarities and differences of proteolytic features of the isolated bacteria. Proteolytic profiles of 72 bacterial strains analyzed for 19 substrates (Table 1) were used as starting data for PCA. The proteolytic profile of each strain was a data set of rel-
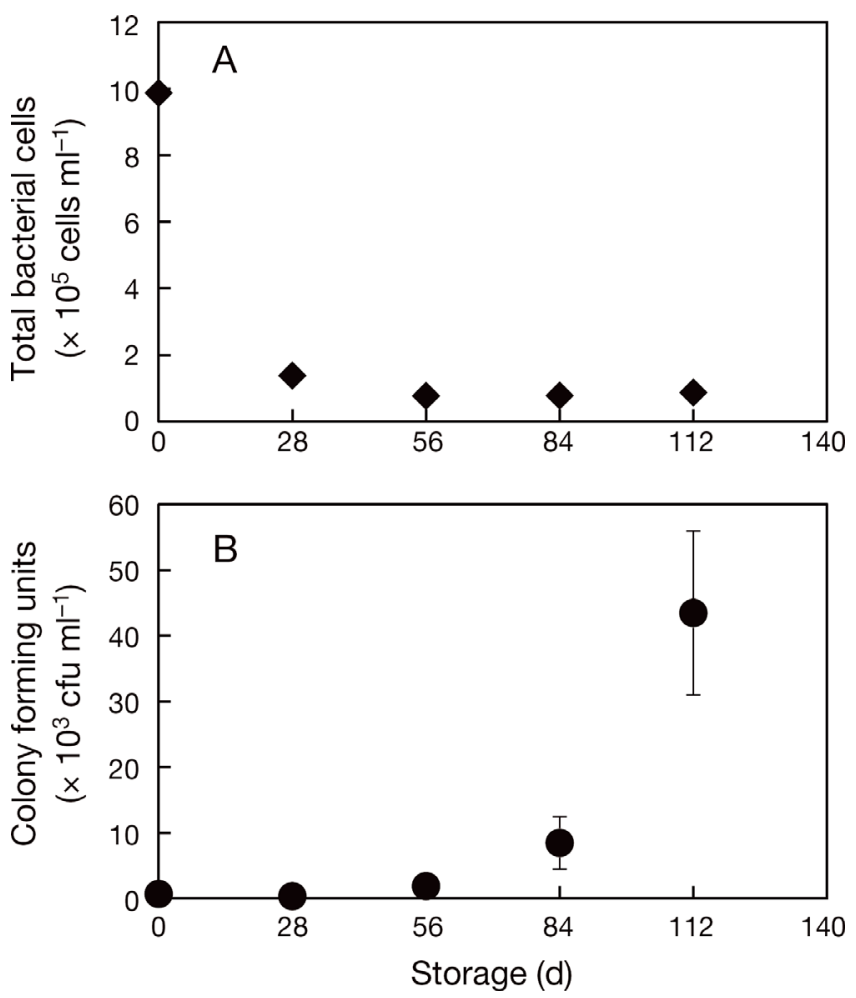

Fig. 1. Time course of (A) total bacterial cell counts and (B) colony forming unit (cfu) counts in stored seawater samples. Error bars represent standard deviations (SD) of triplicate measurements 


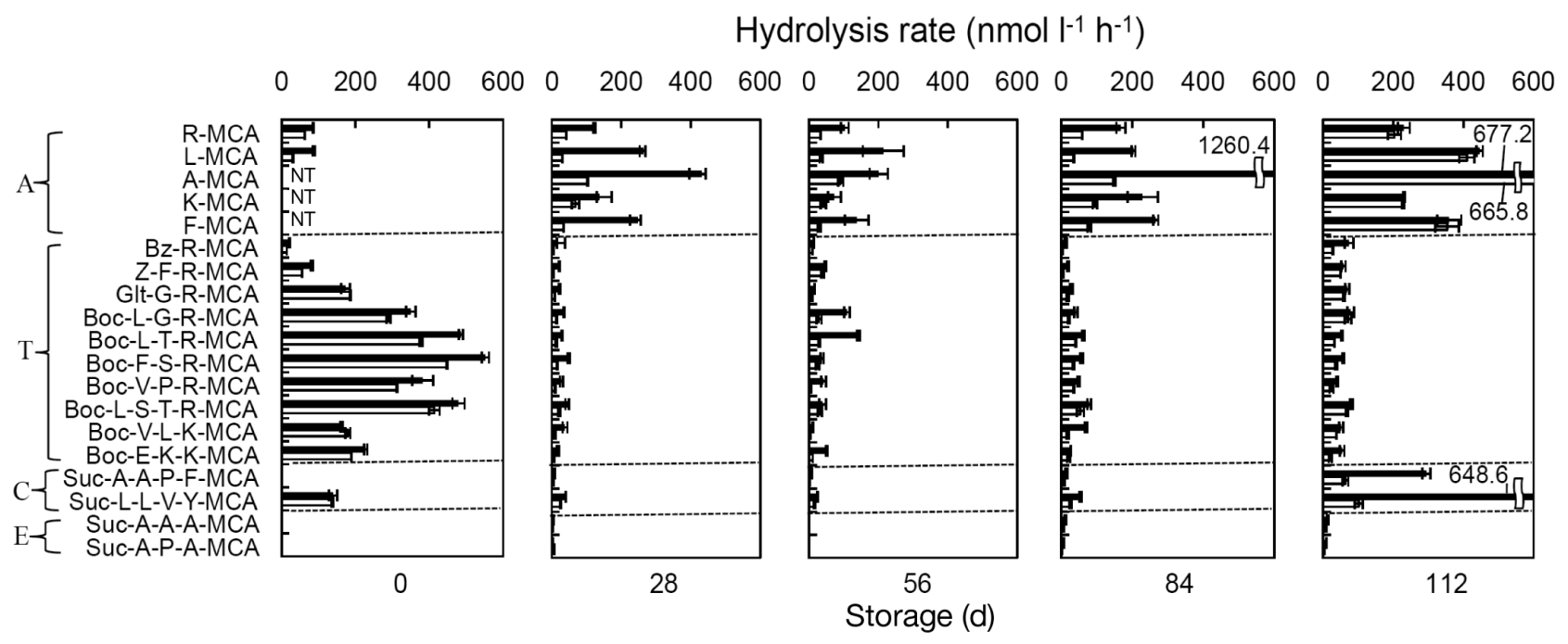

Fig. 2. Mean $( \pm \mathrm{SD})$ hydrolytic activity of unfiltered (filled bars) and $<0.2 \mu \mathrm{m}$ (unfilled bars) fractions in stored seawater. Enzymes are as follows: A: aminopeptidase; T: trypsin; C: chymotrypsin; E: elastase. NT: not tested. See Table 1 for substrate definitions

ative hydrolysis rates of each substrate against the hydrolysis rate of the most hydrolyzed substrate by that strain. PCA in this study was based on the covariance matrix of relative hydrolysis rates of 19 substrates.

\section{RESULTS}

\section{Changes in bacterial numbers in stored seawater}

The total bacterial count decreased from $9.8 \times 10^{5}$ to $1.4 \times 10^{5}$ cells ml ${ }^{-1}$ at Day 28 and remained constant at approximately $0.8 \times 10^{5}$ cells ml ${ }^{-1}$ thereafter (Fig. 1A). The number of colony forming units (cfu) at Day 0 was $6.9 \times 10^{2} \mathrm{cfu} \mathrm{ml}^{-1}$, which decreased to 3.5 $\times 10^{2} \mathrm{cfu} \mathrm{ml}^{-1}$ by Day 28. After Day 28, the cfu count increased, reaching a maximum of $4.4 \times 10^{4} \mathrm{cfu} \mathrm{ml}^{-1}$ at Day 112 (Fig. 1B).

\section{Changes in protease activities in stored seawater}

Fig. 2 shows the changes over time in proteolytic potentials of the unfiltered and $<0.2 \mu \mathrm{m}$ stored seawater fractions at different storage times with 19 different substrates. Trypsin showed the highest activity of the enzymes tested at Day 0. There was a significant $(p<0.05)$ decrease in the hydrolysis potential of the substrates for trypsin from Day 0 to Day 28, and thereafter it remained relatively constant. When the unfiltered and $<0.2 \mu \mathrm{m}$ fractions were compared, more than half of the trypsin activity was attributed to the $<0.2 \mu \mathrm{m}$ fraction.

Aminopeptidase activity significantly increased over time $(\mathrm{p}<0.05$; Fig. 2$)$. The aminopeptidase activity was mainly found in the cellular fraction except for the sample taken at Day 112, where the higher activity ( $>90 \%$ ) was observed in the $<0.2 \mu \mathrm{m}$ fraction. A-MCA was the most hydrolyzed substrate used to test aminopeptidase activity and its rate was twice that of the other substrates.

Chymotrypsin activity was low from the beginning until Day 84 . The increase in chymotrypsin activity observed at Day 112 was mainly attributed to the cellular fraction $(80 \%)$. The elastase activity was mostly low (0 to $12.9 \mathrm{nmol} \mathrm{l}^{-1} \mathrm{~h}^{-1}$ ) throughout the observation period.

\section{Isolation of bacteria from stored seawater}

A total of 72 isolates of 23 genera were obtained from the stored seawater sample. The major phylogenetic groups (with $>95 \%$ identity) identified by $16 \mathrm{~S}$ rDNA analysis are presented in Fig. 3. Thirty isolates

Fig. 3. Neighbor-joining phylogenetic tree showing the position of isolated bacteria from stored seawater at Days 0, 56, 84 and 112 compared with related species based on $16 \mathrm{~S}$ rDNA sequences. Isolates obtained in this work are shown in bold. Nanoarchaeum equitans was used as an out-group. Bootstrap support values $>50$ are indicated at nodes and the scale bar shows 0.1 substitutions per site 


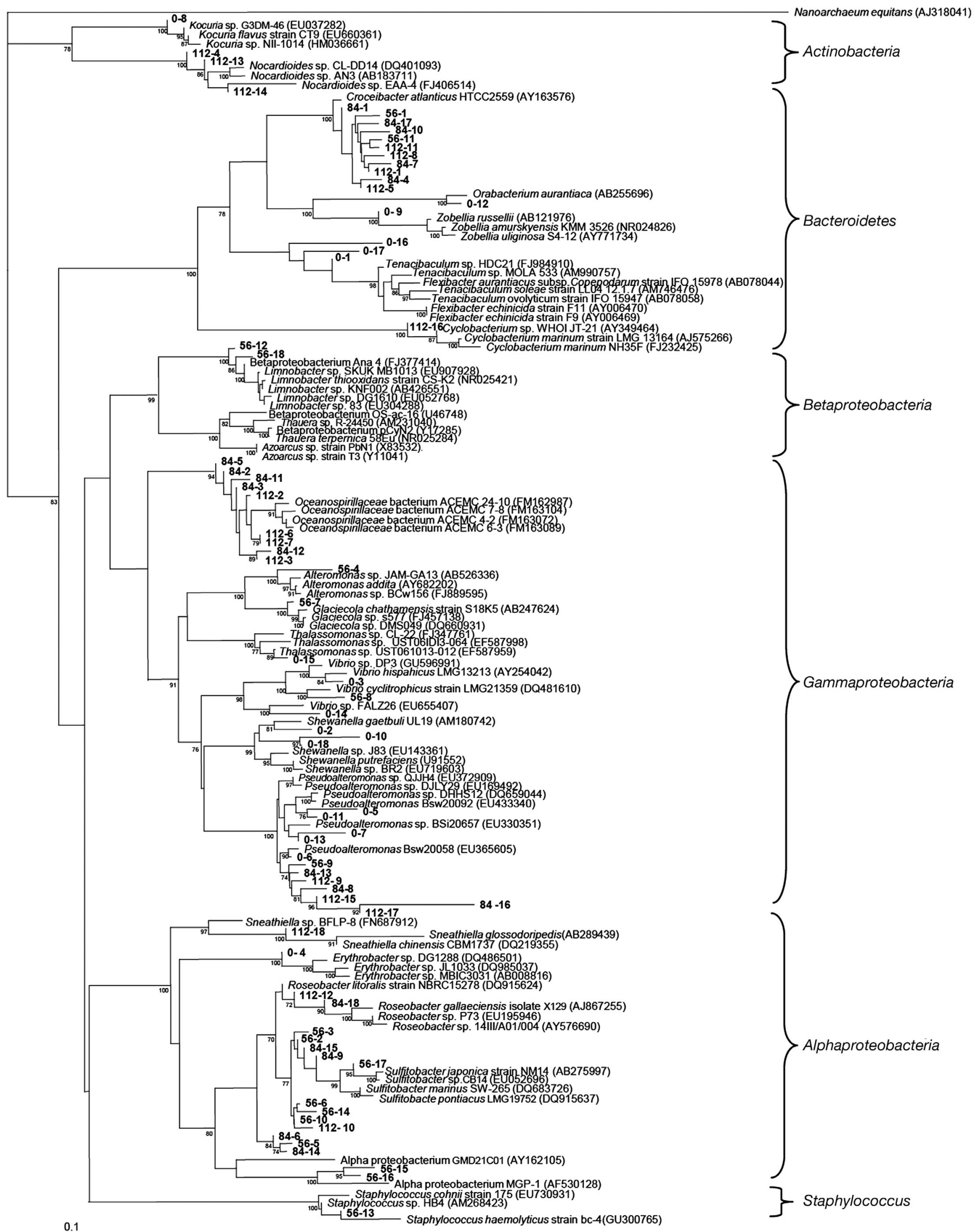


were classified as Gammaproteobacteria, 18 isolates as Alphaproteobacteria and 17 isolates as Bacteroidetes. Only a few isolates belong to the Betaproteobacteria, Actinobacteria and Firmicutes. Among the Gammaproteobacteria, Pseudoalteromonas species were found at all sampling times, whereas Oceanospirillaceae species were only detected on Days 84 and 112. Sulfitobacter (Alphaproteobacteria) and Croceibacter (Bacteroidetes group) species were detected at Day 56 and became dominant at Days 84 and 112 .

\section{Protease profiles of isolated bacteria}

Proteolytic activities of all isolated bacteria from Days 0-112 are shown in Figs. 4-7. The cell-specific activities of bacterial isolates from Day 0 seawater were higher than those from the other days.

Substrates for aminopeptidase were hydrolyzed at the highest rate by most of the bacterial isolates, followed by chymotrypsin and trypsin. Most isolates of Alphaproteobacteria (Sulfitobacter) detected at Days 56, 84 and 112 hydrolyzed only substrates of aminopeptidase at the highest rates. Some isolates of Gammaproteobacteria, Actinobacteria and Staphylococcus hydrolyzed substrates for trypsin at a higher rate. Elastase activity was weak for all isolates.

The isolates belonging to the Bacteroidetes group exhibited the highest aminopeptidase activity for all storage periods except at Day 0. The higher trypsin activity was observed in Gammaproteobacteria and Bacteroidetes in comparison to the other groups of bacteria, while the highest chymotrypsin activity was found in Gammaproteobacteria.

\section{DISCUSSION}

The fate of proteins in seawater is of interest from the viewpoint of organic matter supply to the microbial loop and the biodegradation processes of organic detritus. We examined proteolytic enzyme activities in stored seawater and bacterial isolates to assess their contribution to proteolysis during starvation.

The abundance of bacteria tended to decrease over the $112 \mathrm{~d}$ of this experiment, whilst the abundance of colony-forming bacteria increased (Fig. 1). This suggests that unculturable bacteria decreased, while culturable bacteria increased over time in the stored seawater. This process might depend on physiological adaptation based on nutrient condition (Eilers et al. 2000), or species succession based on evolving selective pressures. Bottle effects probably play a role, concentrating nutrients at surfaces in favor of the high substrate demand of cultivable bacteria (Zobell \& Anderson 1936, Ferguson et al. 1984, Agis et al. 2007).

The trypsin-type activity in seawater at Day 0 was significantly higher $(p<0.05)$ than the aminopeptidase- and chymotrypsin-type activities (Fig. 2). Trypsin typically cleaves the protein backbone adjacent to lysine or arginine (Olsen et al. 2004), and this process is important for protein degradation and carbon and nitrogen recycling. Our results showed that the enzyme profile at the initial stage was quite different from that obtained after a long period of starvation. In the Day 0 seawater, trypsin and chymotrypsin activities were detected in the $<0.2 \mu \mathrm{m}$ fraction, while aminopeptidase activity was mainly found in the cellular fraction. These results are in agreement with the studies by Obayashi \& Suzuki (2008) and Pantoja et al. (1997).

Although many reports indicate that the proteolytic potentials in aquatic systems are mainly associated with the bacterial size fraction (e.g. Rosso \& Azam 1987), dissolved enzymes can contribute to the total activity. Obayashi \& Suzuki (2008) demonstrated that a major portion of trypsin activity in coastal seawater is found in the $<0.2 \mu \mathrm{m}$ fraction, which includes colloids and solutes. Karner \& Rassoulzadegan (1995) reported a significant contribution of the $<0.1 \mu \mathrm{m}$ fraction to aminopeptidase activity in coastal Mediterranean Sea samples. Free enzymes are possibly supplied by autolysis of various cells, viral lysis and protozoan grazing (Chróst 1991, Nagata \& Kirchman 1992; González et al. 1993).

We observed a dramatic increase in the levels of aminopeptidase and chymotrypsin activities in seawater at Day 112 compared with Day 0. The chymotrypsin activity at Day 112 was mainly attributed to the unfiltered fraction while most of the aminopeptidase activity was attributed to the $<0.2 \mu \mathrm{m}$ fraction. Albertson et al. (1990) pointed out that enhanced excretion of extracellular enzymes into the surrounding environment might be correlated with bacterial starvation. Münster (1991) also reported that the activity of extracellular leucine aminopeptidase would be increased when the concentration of dissolved free amino acids in the environment is limited. Therefore, the expression of extracellular enzymes with high substrate affinity might enhance the bacterial assimilation of available organic matter under nutrient-limited conditions.

We isolated heterotrophic bacteria from seawater stored for different time periods and examined their 

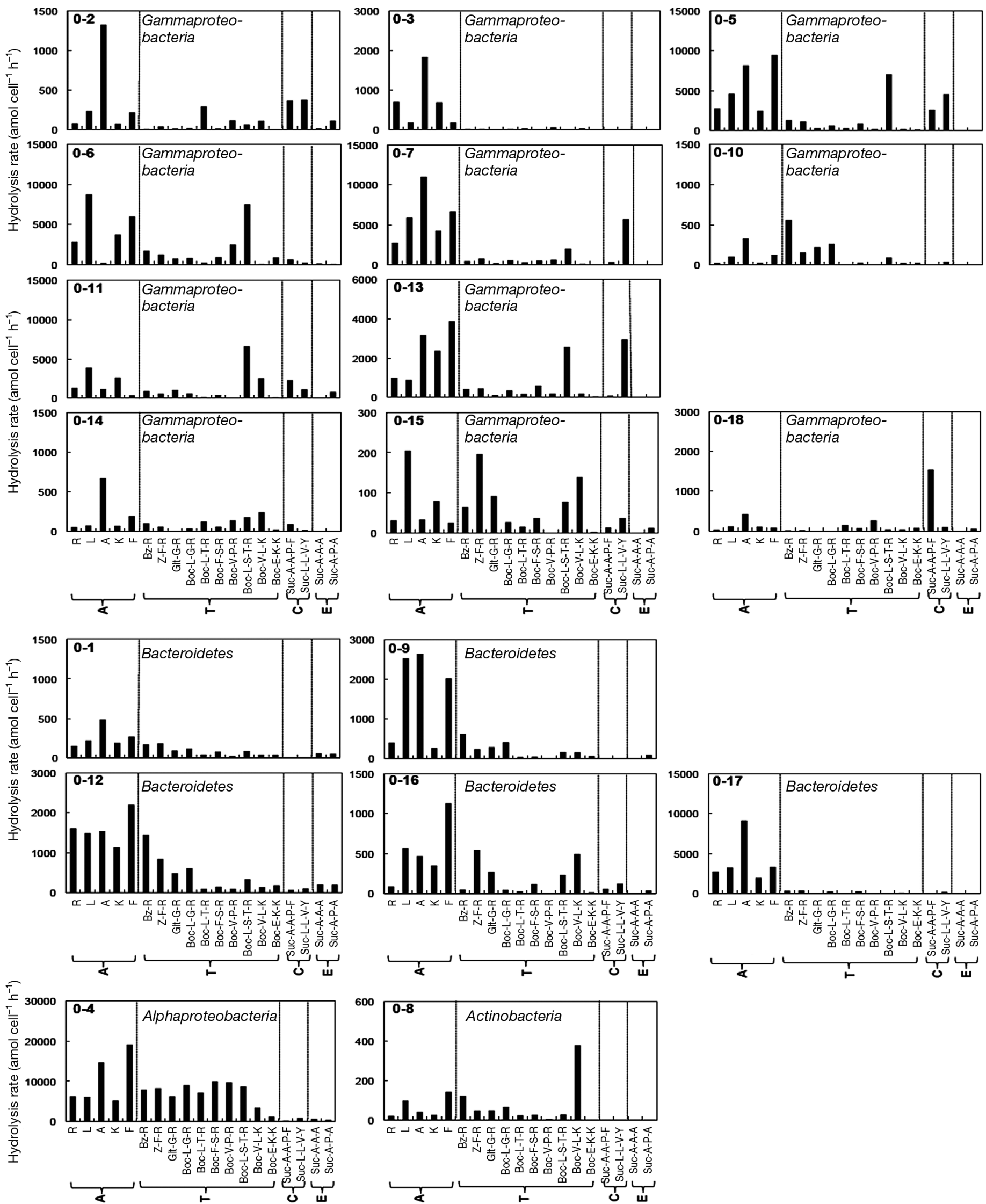

Fig. 4. Proteolytic potentials of bacteria isolated at Day 0 and arranged according to their phylogenetic groups. See Table 1 for substrate definitions and Fig. 2 for enzyme definitions 

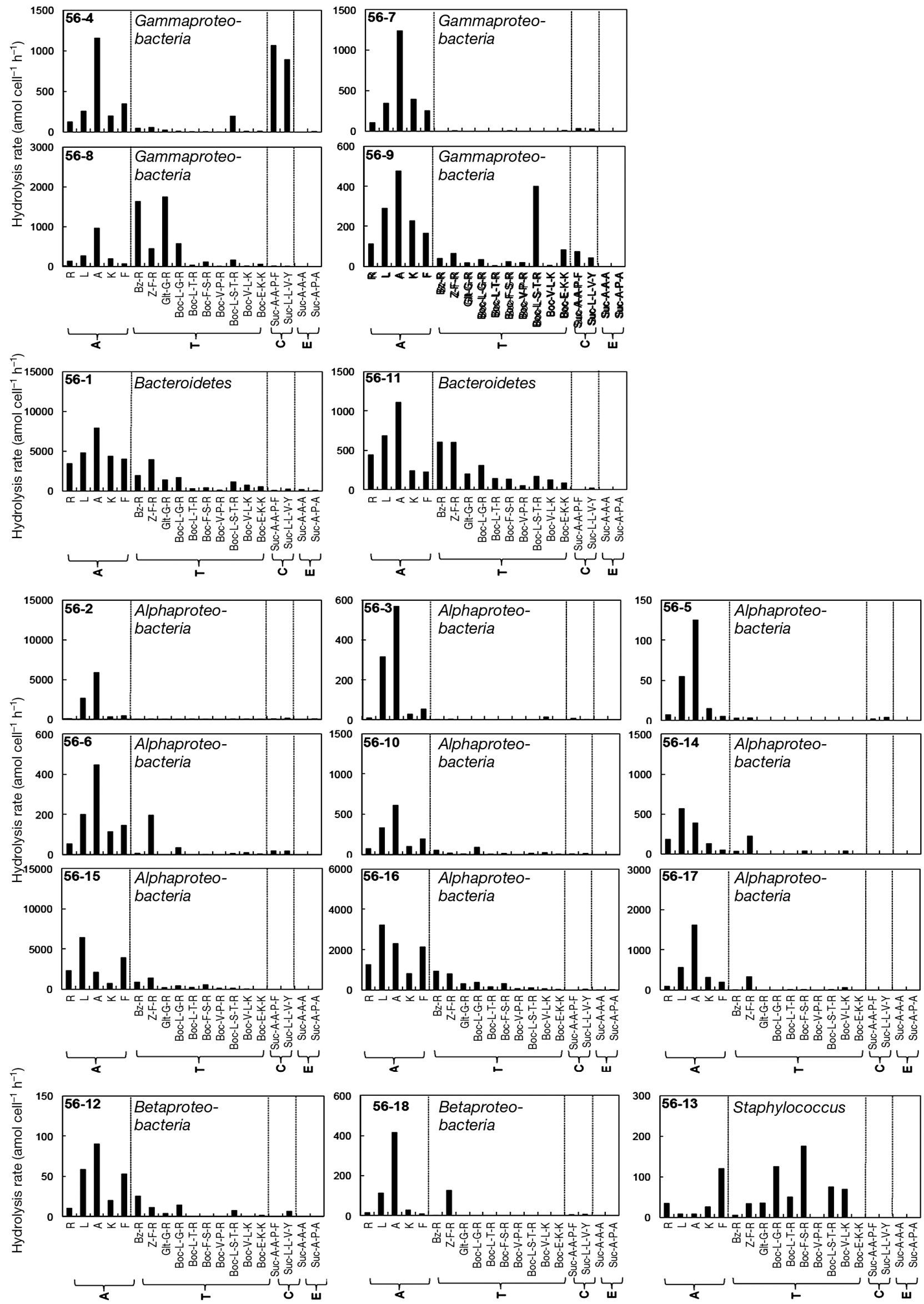

Fig. 5. Proteolytic potentials of bacteria isolated at Day 56. See Table 1 for substrate and Fig. 2 for enzyme definitions 

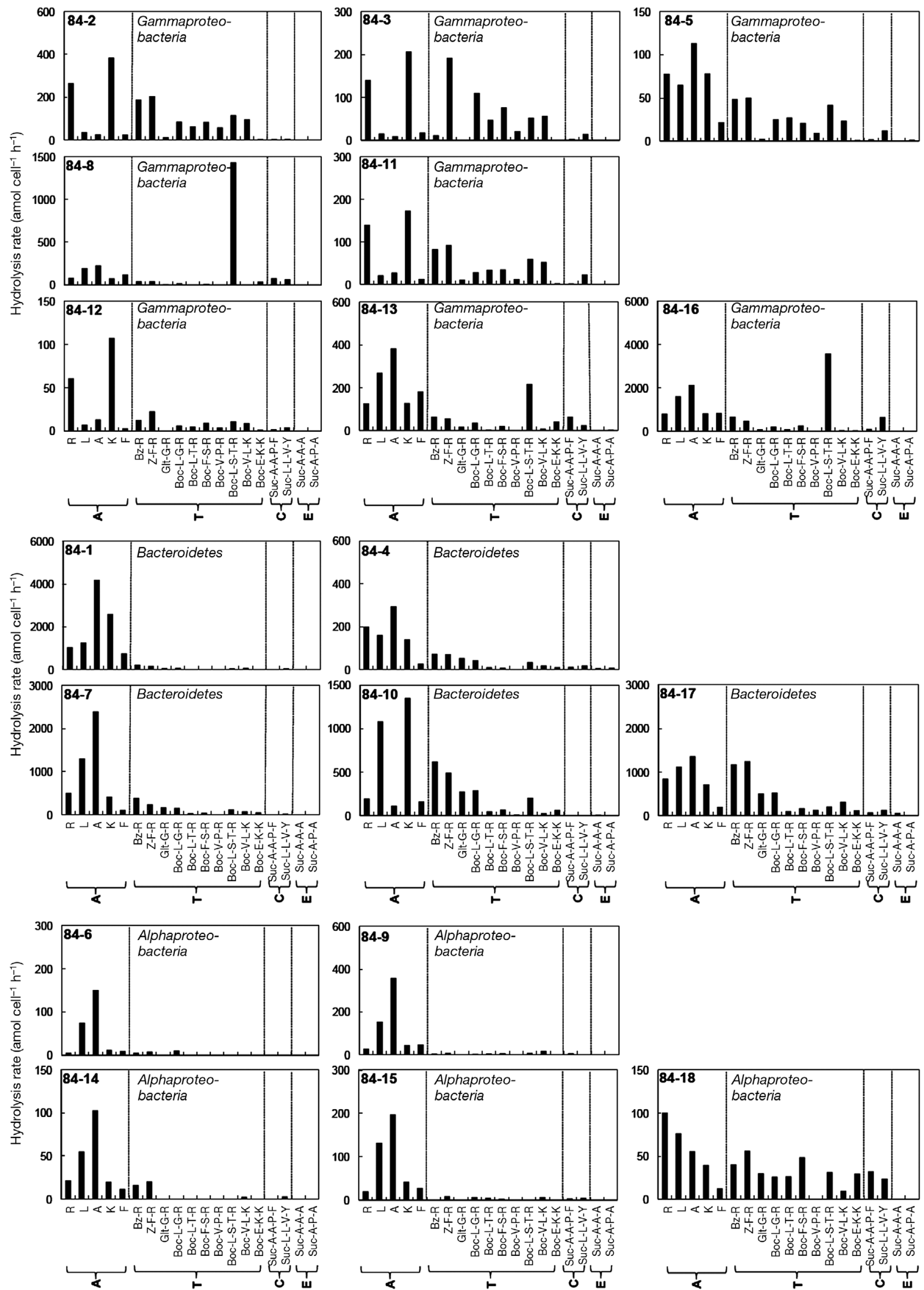

Fig. 6. Proteolytic potentials of bacteria isolated at Day 84. See Table 1 for substrate definitions and Fig. 2 for enzyme definitions 
42

Aqua Micro Ecol 69: 33-46, 2013
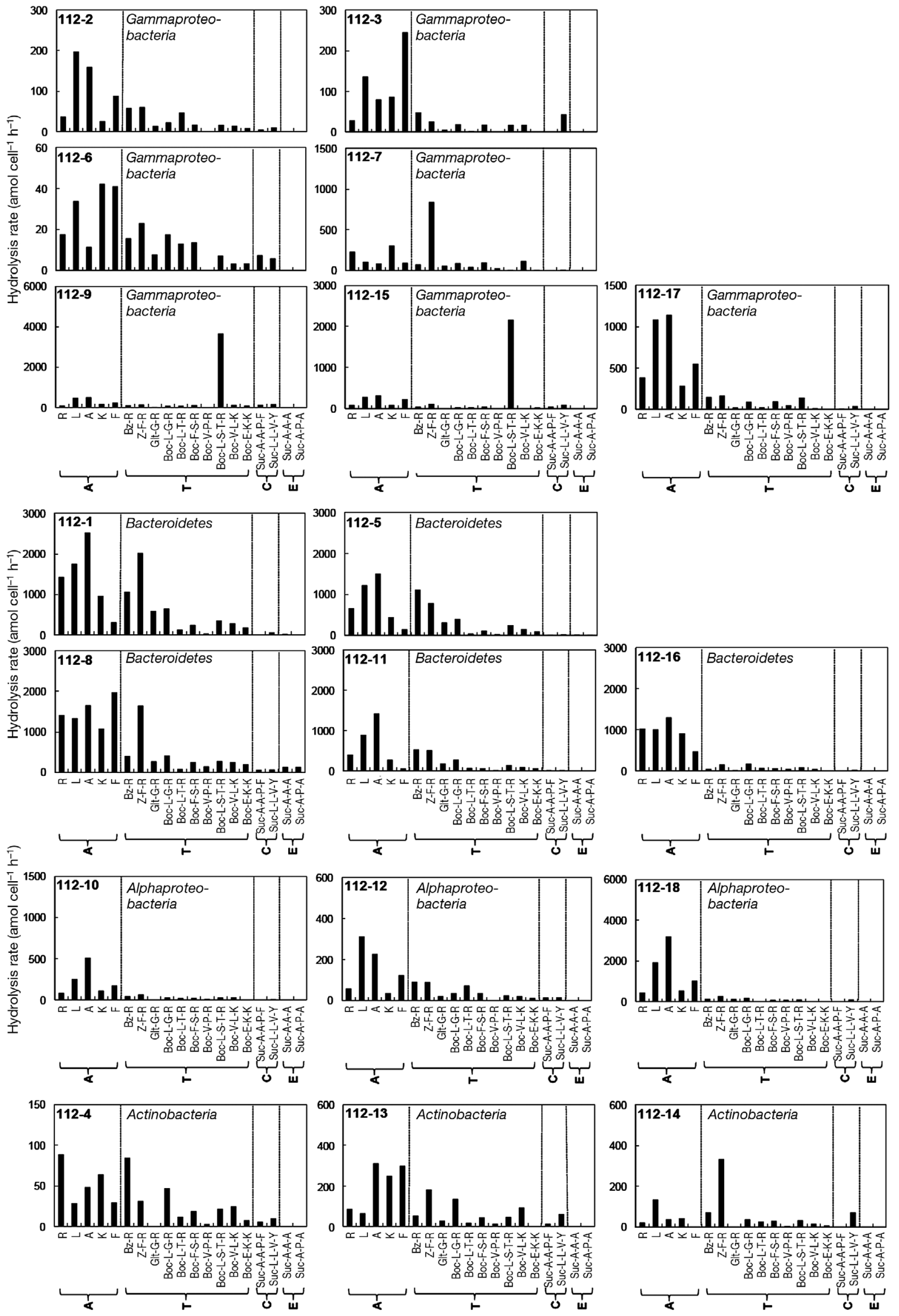

Fig. 7. Proteolytic potentials of bacteria isolated at Day 112. See Table 1 for substrate and Fig. 2 for enzyme definitions 
proteolytic profile (Figs. 4 to 7). The majority of isolated strains belonged to Gammaproteobacteria, Alphaproteobacteria and Bacteroidetes. Although culturable bacteria are not usually expected to completely represent the natural community, these 3 classes are commonly detected in various marine regions (e.g. Cottrell \& Kirchman 2000, Shivaji et al. 2004). Martinez et al. (1996) reported that the enzyme profiles of bacteria isolated from different environments are clearly different and we also report that the proteolytic activity of isolates obtained from different sources (types of proteins) during starvation showed specific profiles. In the aquatic environment, the types of organic matter available for the microbial community can affect the physiological activity of heterotrophic bacteria and the community structure. The bacterial assemblages might take a variable metabolic response to the changes and limitations of nutrients in order to grow and survive in the seawater environment. Starvation responses of marine bacteria have been studied mostly in laboratory cultures of Vibrio sp. and Escherichia coli (Morita 1997, Kjellerberg et al. 1993). All cultures examined to date have some systematic response to starvation, including the synthesis of new proteases, activation of the preexisting enzymes and repression of specific enzymes, which makes the bacteria able to change the nutrient pathways and maximize substrate uptake under the stressful conditions of the marine environment (Ben Abdallah et al. 2007, Siegele \& Kolter 1992, Ben Abdallah et al. 2009). Martinez et al. (1996) reported that the cell-specific enzyme profiles of isolates from eutrophic water bodies were lower than those from oligotrophic water bodies. Baltar et al. (2009, 2010) also demonstrated that isolated bacteria from deepsea water showed particularly high cell-specific enzyme activities.

PCA was used to evaluate the proteolytic features of the 72 isolates and revealed that the first and second principal components accounted for 26.2 and $18.7 \%$ of the variability, respectively. On the crossplot of the first and second principal component scores (Fig. 8A-D), strains isolated from the seawater microcosm at different days $(0,56,84$ and 112) dispersed similarly and any significant differences were not found among their averaged scores (Figs. 8A,C). In contrast, small differences in the averaged scores among the phylogenetic groups (Bacteroidetes, Gamma- and Alphaproteobacteria) were found (Fig. 8D). These results showed that proteolytic features of isolated bacteria might be slightly different among the phylogenetic groups.
In general, it is difficult to define exact meanings of the principal components in PCA methodology. However, a cross-plot of the factor coefficients of the first and second principal components is helpful in considering the variability of the scores and the characteristics of the samples. In Fig. 8E, all 'aminopeptidase' appears in the upper region, indicating that the second principal component scores rise when the relative importance of aminopeptidase activity in the sample is high. Conversely, the relative importance of 'chymotrypsin' causes a downward shift in the second principal component score. All 'trypsin' in Fig. 8E appeared in the right region, indicating that the first principal component scores of the sample should be higher when the importance of trypsin type activity is high. Comparing the position on the cross-plot among phylogenetic groups (Fig. 8B,D), most of the Alphaproteobacteria characteristically showed a higher aminopeptidase activity. Most of the Bacteroidetes strains were also characterized by a high importance of aminopeptidase and, for some of them, trypsin activity. Although Gammaproteobacteria and Actinobacteria were scattered on the cross-plot, some of them seemed to exhibit a higher importance of trypsin and chymotrypsin activity.

The results of the PCA imply that the proteolytic features of bacteria depend more on their phylogenetic classification than the nutritional conditions, at least in the case of culturable strains from our microcosm. In other words, a variety of bacteria with different proteolytic features exist together under any nutritional conditions. This might be the mechanism by which various organic matters are efficiently utilized in the aquatic environment. This ability to utilize various forms of organic matter, even in changing environments, could also be important in complex natural aquatic ecosystems. Martinez et al. (1996) proposed that a shift in species composition could strongly influence the rates and patterns of polymer and particle hydrolysis in the sea. Furthermore, protease activity increased in a proteinenriched microcosm (Pinhassi et al. 1999). Our results indicate that each bacterial group produced specific proteases contributing to proteolysis in the bacterial community by a combined action.

In conclusion, we have provided evidence for the variability of proteolytic extracellular enzymes in seawater and bacteria isolated from seawater over time. The results suggest that as the community structure changes, various bacterial members compensate each other, driving the protein degradation cascade. 

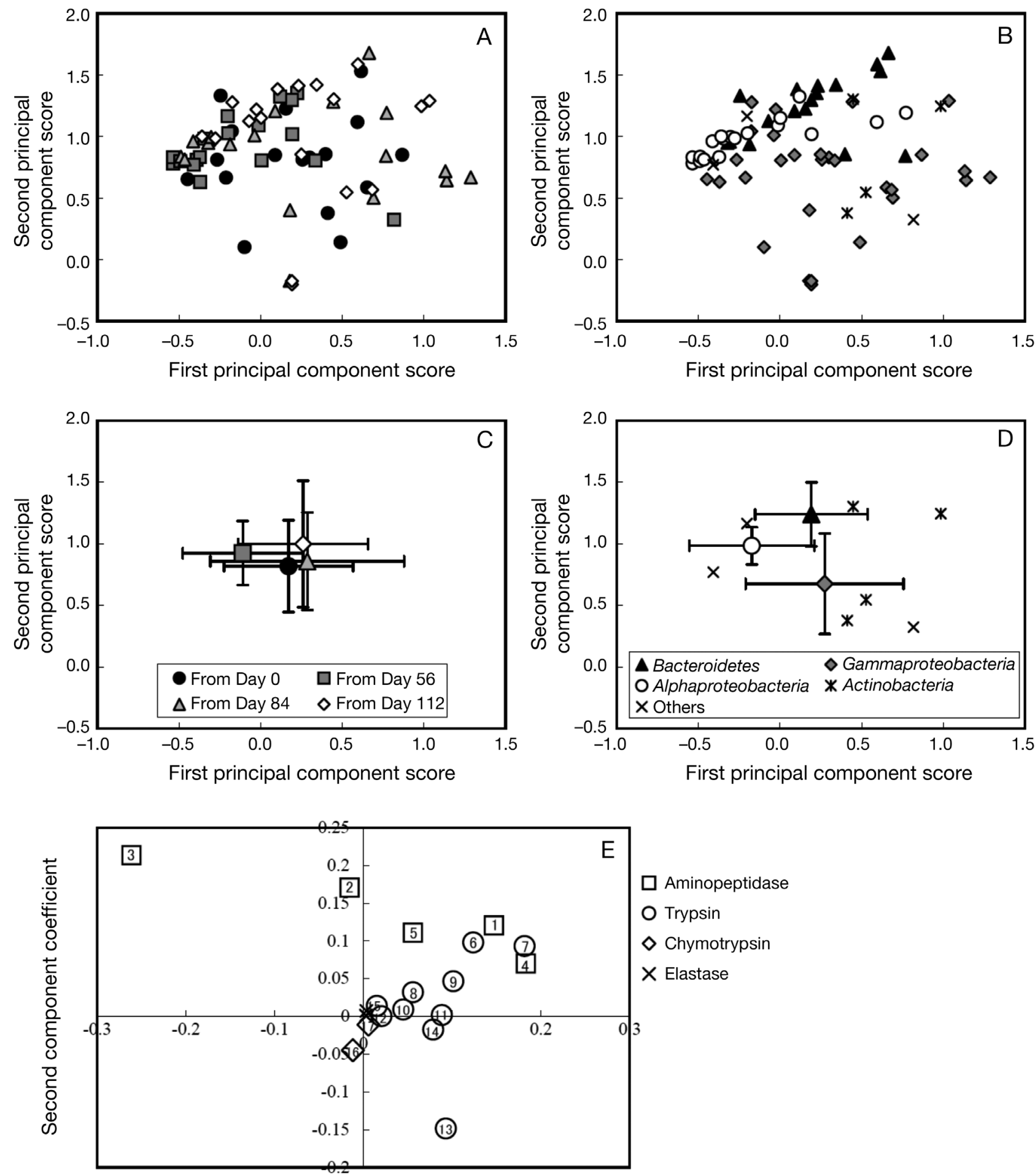

First component coefficient

Fig. 8. Results of principal component analysis based on proteolytic profiles of isolated bacteria. (A) Cross-plot of the first and second principal component scores for each strain isolated from Days 0, 56,84 and 112. Symbols are defined in C. (B) As A, but the symbols are defined by each phylogenetic group of the isolated strain (defined in D). (C,D) As A and B, but the principal component scores are averaged for each group of isolates, except for Actinobacteria and 'others' in D. Error bars indicate \pm 1 $\mathrm{SD}$ of the scores in each group. (E) Cross-plot of the first and second component coefficients of the relative hydrolytic rate of each MCA substrate. Symbols are defined by substrates for aminopeptidase, trypsin, chymotrypsin and elastase. Numbers in the symbols represent the substrate name as given in Table 1 
Acknowledgements. This manuscript was improved by the comments of Professor H-G. Hoppe and 4 anonymous reviewers. We thank Dr. Todd W. Miller for his critical reading of this paper. This study was partly supported by 21 st Century COE and Global COE Programs at Ehime University, and a Grant-in-aid for scientific research from the Ministry of Education, Culture, Sports, Science and Technology (MEXT), Japan. Chui Wei Bong was financially supported by the Government of Malaysia.

\section{LITERATURE CITED}

Agis M, Granda A, Dolan JR (2007) A cautionary note: examples of possible microbial community dynamics in dilution grazing experiments. J Exp Mar Biol Ecol 341: 176-183

> Albertson NH, Nyström T, Kjelleberg S (1990) Exoprotease activity of two marine bacteria during starvation. Appl Environ Microbiol 56:218-223

Azam F, Worden AZ (2004) Microbes, molecules and marine ecosystems. Science 303:1622-1624

- Baltar F, Sintes E, Van Aken H, Gasol JM, Arístegui J, Herndl GJ (2009) Prokaryotic extracellular enzymatic activity in relation to biomass production and respiration in the meso- and bathypelagic waters of the (sub) tropical Atlantic. Environ Microbiol 11:1998-2014

> Baltar F, Arístegui J, Gasol JM, Sintes E, van Aken HM, Herndl GJ (2010) High dissolved extracellular enzymatic activity in the deep central Atlantic Ocean. Aquat Microb Ecol 58:287-302

Ben Abdallah F, Chaieb K, Snoussi M, Bakhrouf A, Gaddour K (2007) Phenotypic variations and molecular identification of Salmonella enterica serovar Typhimurium cells under starvation in seawater. Curr Microbiol 55:485-491

Ben Abdallah F, Chaieb K, Kallel H, Bakhrouf A (2009) RTPCR assays for in vivo expression of Vibrio alginolyticus virulence genes in cultured gilthead Dicentrarchus labrax and Sparus aurata. Ann Microbiol 59:1-5

Benner R (2002) Chemical composition and reactivity. In: Hansell DA, Carlson C A (eds) Biogeochemistry of marine dissolved organic matter. Academic Press, San Diego, CA, p 59-90

Benner R, Chin-Leo G, Gardner W, Eadie B, Cotner J (1992) The fates and effects of riverine and shelf-derived DOM on Mississippi River plume/Gulf shelf processes. Proceedings of the Workshop on Nutrient Enhanced Coastal Ocean Productivity. National Oceanic and Atmospheric Administration, Coastal Ocean Program Office, Texas SeaGrant, Galveston, TX, p 84-94

Chróst RJ (1991) Environmental control of the synthesis and activity of aquatic microbial ectoenzymes. In: Chrost R (ed) Microbial enzyme in aquatic environments. Series in contemporary bioscience. Brock/Springer Verlag, Berlin, p 29-59

> Cottrell MT, Kirchman DL (2000) Natural assemblages of marine proteobacteria and members of the CytophagaFlavobacter cluster consuming low- and high molecular weight dissolved organic matter. Appl Environ Microbiol 66:1692-1697

- Eilers H, Pernthaler J, Glöckner FO, Amann R (2000) Culturability and in situ abundance of pelagic bacteria from the North Sea. Appl Environ Microbiol 66:3044-3051

> Ferguson RL, Buckley EN, Palumbo AV (1984) Response of marine bacterioplankton to differential filtration and confinement. Appl Environ Microbiol 47:49-55

González JM, Sherr EB, Sherr BF (1993) Differential feeding by marine flagellates on growing versus starving, and on motile versus nonmotile, bacterial prey. Mar Ecol Prog Ser 102:257-267

Hoppe HG (1983) Significance of exoenzymatic activities in the ecology of brackish water: measurements by means of methylumbelliferyl-substrates. Mar Ecol Prog Ser 11: 299-308

Hoppe HG, Arnosti C, Herndl GJ (2002) Ecological significance of bacterial enzymes in the marine environment. In: Burns RG, Dick RP (eds) Microbial enzymes in the environment: activity, ecology and applications. Marcel Dekker, New York, p 73-107

Karner M, Rassoulzadegan F (1995) Extracellular enzyme activity: indications for high short-term variability in a coastal marine ecosystem. Microb Ecol 30:143-156

Keil RG, Kirchman DL (1993) Dissolved combined amino acids: chemical form and utilization by marine bacteria. Limnol Oceanogr 38:1256-1270

Kjelleberg S, Albertson N, Flärdh K, Holmquist L and others (1993) How do non-differentiating bacteria adapt to starvation? Antonie Leeuwenhoek. 63:331-341

Martinez J, Smith DC, Steward GF, Azam F (1996) Variability in ectohydrolytic enzyme activities of pelagic marine bacteria and its significance for substrate processing in the sea. Aquat Microb Ecol 10:223-230

Morita RY (1997) Bacteria in oligotrophic environments. Chapman \& Hall, New York, NY

Münster U (1991) Extracellular enzyme activity in eutrophic and polyhumic lakes. In: Chróst RJ (ed) Microbial enzymes in aquatic environments. Springer-Verlag, New York, NY, p 96-122

Muyzer G, de Waal EC, Uitterlinden AG (1993) Profiling of complex microbial populations by denaturing gradient gel electrophoresis analysis of polymerase chain reaction-amplified genes coding for 16S rRNA. Appl Environ Microbiol 59:695-700

Nagata T (2008) Organic matter-bacteria interactions in seawater. In: Kirchman DL (ed) Microbial ecology of the oceans, 2nd edn. John Wiley \& Sons, New York, NY, p 207-241

Nagata T, Kirchman DL (1992) Release of dissolved organic matter by heterotrophic protozoa: implications for microbial food webs. Arch Hydrobiol 35:99-109

Nikaido H, Vaara M (1985) Molecular basis of bacterial outer membrane permeability. Microbiol Rev 49:1-32

> Obayashi Y, Suzuki S (2005) Proteolytic enzymes in coastal surface seawater: significant activity of endopeptidases and exopeptidases. Limnol Oceanogr 50:722-726

Obayashi Y, Suzuki S (2008) Occurrence of exo- and endopeptidases in dissolved and particulate fractions of coastal seawater. Aquat Microb Ecol 50:231-237

Obayashi Y, Ueoka N, Suzuki S (2010) Degradation and utilization of protein derived from Pseudomonas aeruginosa by marine microbial community. J Oceanogr 66:513-521

Odagami T, Morita J, Takama K, Suzuki S (1994) Substrate specificities of extracellular proteases produced by marine putrefactive bacteria Shewanella putrefaciens and Alteromonas haloplanktis. Lett Appl Microbiol 18:50-52

> Olsen JV, Ong SE, Mann M (2004) Trypsin cleaves exclusively C-terminal to arginine and lysine residues. Mol Cell Proteomics 3:608-614

Pantoja S, Lee C, Marecek JF (1997) Hydrolysis of peptides in seawater and sediment. Mar Chem 57:25-40 
Pinhassi J, Azam F, Hemphälä J, Long RA, Martinez J, Zweifel UL, Hagström Å (1999) Coupling between bacterioplankton species composition, population dynamics, and organic matter degradation. Aquat Microb Ecol 17: $13-26$

Rosso AL, Azam F (1987) Proteolytic activity in coastal oceanic waters: depth distribution and relationship to bacterial populations. Mar Ecol Prog Ser 41:231-240

Sharp JH (1983) The distribution of inorganic nitrogen and dissolved and particulate organic nitrogen in the sea. In: Carpenter EG, Capone DG (eds) Nitrogen in the marine environment. Academic Press, New York, NY, p 1-35

Shivaji S, Reddy GSN, Aduri RP, Kutty R, Ravenschlag K (2004) Bacterial diversity of a soil sample from Schirmacher Oasis Antarctica. Cell Mol Biol 50:525-536

Siegele DA, Kolter R (1992) Life after log. J Bacteriol 174: 345-348

Smith DC, Simon M, Alldredge AL, Azam F (1992) Intense

Editorial responsibility: Hans-Georg Hoppe, Kiel, Germany hydrolytic enzyme activity on marine aggregates and implications for rapid particle dissolution. Nature 359: 139-142

Taylor GT, Thunell R, Varela R, Benitez-Nelson C, Scranton MI (2009) Hydrolytic ectoenzyme activity associated with suspended and sinking organic particles within the anoxic Cariaco Basin. Deep-Sea Res I 56:1266-1283

- Thompson JD, Gibson TJ, Plewniak F, Jeanmougin F, Higgins DG (1997) The Clustal X windows interface: flexible strategies for multiple sequence alignment aided by quality analysis tools. Nucleic Acids Res 25:4876-4882

Thurman EM (1985) Organic geochemistry of natural waters. Martinus Nijhoff/Dr. W. Junk Publishers, Dordrecht

Zobell CE, Anderson DQ (1936) Observations on the multiplication of bacteria in different volumes of stored sea water and the influence of oxygen tension and solid surfaces. Biol Bull 71:324-342

Submitted: June 2, 2010; Accepted: January 25, 2013

Proofs received from author(s): March 15, 2013 